\title{
SEVERITY EVALUATION METHODS FOR SOUTHERN POLYSORA CORN RUST
}

\author{
MÉTODOS DE AVALIAÇÃO DA SEVERIDADE DA FERRUGEM POLYSORA DO \\ MILHO
}

\author{
Fernando Cezar JULIATTI ${ }^{1}$; Adriana Andrade FIGUEIRÓ ${ }^{2}$; Élcio Oliveira ALVES ${ }^{3}$ \\ 1. Professor, Doutor, Instituto de Ciências Agrárias - ICIAG, Universidade Federal de Uberlândia, Uberlândia, MG, Brasil; 2.Bióloga, \\ Mestre em Fitopatologia e Doutora em Fitotecnia pela UFRGS. Pós Doutorado-CAPES, LAMIP-ICIAG-UFU, Uberlândia, MG, Brasil; \\ 3. Engenheiro Agrônomo, Pioneer Sementes, Itumbiara, GO, Brasil
}

\begin{abstract}
Among the biotrophic organisms that attack the corn crop the most important for Central Brazil is the Puccinia polysora Underw, which is the causal agent of polysora corn rust. Due to the need to study the methods used in the assessments better, this work was performed. An experiment to identify the best methodology for assessing polysora rust was set up in Itumbiara - Goiás - Brazil, with 22 hybrids and an experimental randomized block design with three replications. So as to evaluate disease severity in relation to the leaf area affected, the Area Under the Disease Progress Curve (AUDPC) and a single evaluation were used, while also considering the severity of the disease on the leaf area affected, 30 days after flowering (30 d.a.f.) Both based on a proposal diagrammatic scale from Agroceres with grades ranging from one (highly resistant) to nine (highly susceptible), which were employed considering the plot as a whole. So as to calculate the AUDPC five evaluations of disease severity at intervals of 10 days which begun 50 days after sowing were carried out. It was found that it was possible to determine the level of genotype resistance by using the AUDPC or by using the single assessment at 30 d.a.f., with the assessment of disease severity by means of the AUDPC calculation allowing for better understanding of the evolution of the disease in time and that the one only or single assessment at 30 d.a.f. allows us to work with a greater number of genotypes, due to the practicality of the methodology.
\end{abstract}

KEYWORDS: Puccinia polysora. Evaluation. Disease. Rust.

\section{INTRODUCTION}

Since the beginning of the 1980 s, polysora rust, Puccinia polysora Underw, has been a serious problem in the corn crop in south-west regions of Goias, in the Triângulo Mineiro and more recently in the northwest of São Paulo, in the East and in the North of Paraná and in Mato Grosso do Sul in Brazil. It is considered to be the most aggressive and destructive among corn diseases and can cause rapid necrosis of the plant. Under favorable conditions and in susceptible cultivars, this rust may occur with severe presence in the leaves, stems, straw, and hence cause a marked reduction in the size of the corn cobs and grains (FANTIN, 1997).

The severity of the disease can be assessed by subjective methods such as counting the number of lesions per leaf or the measurement of the affected area, but these methods are usually very time consuming. The quantification of disease severity can be carried out visually by means of numeric scales, grades or percentage and diagrammatic procedures (JULIATTI; SANTOS, 1999).

As corn breeding or improvement programs are very dynamic, and produce a large number of new varieties each year, it is necessary to evaluate the behavior of these materials in relation to this disease. This, not only so as to direct future work of breeding/improvement, in order to obtain resistant cultivars, but also to act as a guide in the selection and recommendation of cultivars for different regions (VON PINHO et al., 2001).

The less costly and more efficient control method for polysora rust is the use of hybrids or varieties with satisfactory levels of resistance to the pathogen (BALMER; PEREIRA, 1987; McGEE, 1988; PEREIRA, 1997; PINTO et al., 1997; SHERF; MACNAB, 1986). The objective of this work was to compare the effectiveness of methods used in the severity analysis of polysora corn rust.

\section{MATERIAL AND METHODS}

The trial was conducted at the Pioneer Seeds Ltd. Research Center, in Itumbiara GO, in the period from October 29, 2003 to March 10, 2004. The altitude at the location is $511 \mathrm{~m}$, at coordinates $\mathrm{S} 18^{\circ} 19.995$ and $\mathrm{W} 49^{\circ} 12.101$ and the soil is of medium texture (sandy clay), with an approximate slope of $1 \%$. The average annual rainfall is 1,450 $\mathrm{mm}$, with a minimum annual average temperature of $20{ }^{\circ} \mathrm{C}$ and maximum $30{ }^{\circ} \mathrm{C}$.

The preparation of the area was carried out using a disk harrow (26" disks) and then a leveling harrow to complete the preparation. 
The fertilization of the planting area was made with $500 \mathrm{~kg} \cdot \mathrm{h}^{-1}$ of $08-18-20$ formula $+\mathrm{Zn}$, based on previous analysis of the soil. The topdressing was carried out using $120 \mathrm{~kg}$ of $\mathrm{N}$ divided into two applications of urea $(44 \% \mathrm{~N})$, at 25 and 35 days after sowing (d.a.s.), respectively.

The pre-emergent herbicide Agimix (Atrazine 26\% + Metolachlor 26\%) was used at a dose rate of 5 L.ha ${ }^{-1}$ for weed control. For insect control the Lorsban BR480 products (Chlorpirifos 48\%) were used at the dosages specified by the manufacturer, at V3 and V5 phenological stages, and Lannate BR (Methomil 21.5\%) product, also at the dosage recommended by the manufacturer at V8 and V10 phenological stages.

The experimental design was that of randomized blocks, combining 22 hybrids with different levels of genetic resistance, randomly distributed in three blocks (Table 1).
Seeds were sown on October $29^{\text {th }} 2003$. The plots were formed by three lines of $5 \mathrm{~m}$, spaced at $0.75 \mathrm{~m}$ between rows, with a total used area of $11.25 \mathrm{~m}$ per plot and $495 \mathrm{~m}^{2}$ of total experiment area. To evaluate the severity of the polysora rust and harvesting the overall plot was considered.

The $P$. polysora inoculum was obtained from urediniospores collected from the 30F53 hybrid, a hybrid not adapted to the region and highly susceptible to the pathogen. The urediniospores were collected using a paintbrush and a tray which was lined with foil and were subsequently packed in gelatin capsules until the time of inoculation, carried out on the same day. The inoculum was prepared at a concentration of $1 \times 10^{5}$ urediniosporos. $\mathrm{mL}^{-1}$ solution plus 0,05 $\mu \mathrm{L} . \mathrm{mL}^{-1}$ of Tween 20 ; thereupon the inoculum was homogenized for 10 minutes.

Table 1. Agronomic characteristics of the hybrids used in the test.

\begin{tabular}{lllll}
\hline Identification of Hybrid Type of Hybrid & Cycle & Company & Grain Type \\
\hline AG7000 & Simple & Average & Agroceres & Medium hard \\
AG7575 & Simple & Early & Agroceres & Medium hard \\
2 C577 & Simple & Early & Dow AgroSciences & Semi-dent \\
2C599 & Simple & Early & Dow AgroSciences & Medium hard \\
DKB350 & Triple & Average & Monsanto & Medium hard \\
30F53 & Simple & Early & Pioneer & Medium hard \\
30P70 & Simple & Early & Pioneer & Medium hard \\
30R50 & Simple & Early & Pioneer & Medium hard \\
DKB390 & Simple & Average & Monsanto & Medium hard \\
30F80 & Simple & Semi-early & Pioneer & Hard \\
30F88 & Simple & Semi-early & Pioneer & Hard \\
30F90 & Simple & Semi-early & Pioneer & Hard \\
30K75 & Simple & Semi-early & Pioneer & Medium hard \\
Fort & Simple & Early & Syngenta & Hard \\
Strike & Simple & Early & Syngenta & Hard \\
Tractor & Double & Early & Syngenta & Hard \\
Valent & Triple & Early & Syngenta & Hard \\
AG9010 & Simple & Super-early & Monsanto & Hard \\
30F33 & Simple & Early & Pioneer & Hard \\
$30 F 44$ & Simple & Early & Pioneer & Medium hard \\
Speed & Simple & Super-early & Syngenta & Hard \\
3081 & Simple & Super-early & Pioneer & Hard \\
\hline
\end{tabular}


The inoculation was carried out in borders containing the highly susceptible hybrid, 30F53, at the V8-V10 stage, about 20 days before flowering, so that these function as disseminator lines of the pathogen.

To estimate the Area Under Disease Progress Curve (AUDPC) five evaluations of disease severity were performed. The first evaluation was performed 50 days after sowing (d.a.s.), the others at $60,70,80$ and 90 d.a.s., respectively.

For the evaluations the total experimental plot system was used, which consisted in assessing disease severity in relation to the percentage of leaf area affected of all the experimental plot, according to the diagrammatic scale of Agroceres Health Guide (AGROCERES, 1996) (Table 2).

Table 2. Leaf area affected by the disease, and the corresponding score according to the AGROCERES (1996) diagrammatic scale.

\begin{tabular}{cc}
\hline Original Score & Leaf Area $(\%)$ \\
\hline 9 & 100 \\
8 & 90 \\
7 & 80 \\
6 & 70 \\
5 & 50 \\
4 & 30 \\
3 & 10 \\
2 & 0,5 \\
1 & 0 \\
\hline
\end{tabular}

The AUDPC was calculated from the disease progress curve, based on the percentage of leaf area affected in the experimental plot:

$$
A U D P C=\sum_{i=1}^{n-1} \frac{\left(Y_{i+1}+Y_{i}\right)}{2} x\left(T_{i+1}-T_{i}\right)
$$

In which: $Y_{\mathrm{i}}$ : disease severity at the time of evaluation $i(i=1, \ldots, n), Y_{i+1}$ : disease severity at time of evaluation $\mathrm{i}+1, \mathrm{~T}_{\mathrm{i}}$ : time of evaluation $\mathrm{i}$ (number of days after plant emergence), $\mathrm{T}_{\mathrm{i}+1}$ : time of evaluation $\mathrm{i}+1$ and $\mathrm{n}$ : total number of observations.

For AUDPC data obtained in the plot, the statistical model used for the variance analysis was as follows, considering all effects as fixed, except the experimental error:

$$
\mathrm{Y}_{\mathrm{ij}}=\mathrm{m}+\mathrm{g}_{\mathrm{i}}+\mathrm{b}_{\mathrm{j}}+\mathrm{e}_{\mathrm{ij}}
$$

In which: $Y_{\mathrm{ij}}$ : AUDPC of genetic material $\mathrm{i}$ in block $\mathrm{j}, \mathrm{m}$ : average overall effect, $\mathrm{g}_{\mathrm{i}}$ : effect of genetic material $(i=1,2, \ldots, 22), b_{j}$ : effect of block $j(j$ $=1, \ldots, 3)$ and $e_{i j}$ : effect of experimental error.

To determine the severity of the disease in a single assessment the assessment at 30 days after the average flowering (d.a.f.) of the plot was considered.

Harvesting was carried out using a Wintersteiger harvester in which data as to grain weight and moisture were collected simultaneously. The whole plot was considered for harvesting. Data were analyzed using the SANEST ${ }^{1}$ program for the F test, and average (Tukey) test.

For the yield data obtained at plot level, the statistical model used for variance analysis was as follows, considering all effects as fixed, except the experimental error:

$$
\begin{aligned}
& Y_{i j}=m+g_{i}+b_{j}+e_{i j} \\
& \text { In which: } Y_{i j} \text { : Productivity of genetic }
\end{aligned}
$$
material $\mathrm{i}$ in block $\mathrm{j}, \mathrm{m}$ : average overall effect, $\mathrm{g}_{\mathrm{i}}$ : effect of genetic material $(i=1,2, \ldots, 22), b_{j}$ : effect of block $\mathrm{j}(\mathrm{j}=1, \ldots, 3)$ and $\mathrm{e}_{\mathrm{ij}}$ : effect of experimental error.

Resistance classification by AUDPC was based on Table 3, which was established after analysis of data obtained in experiment.

Resistance classification by severity at 30 days after flowering (d.a.f.) was based on Table 6 .

The average maximum temperature in the culture over the period was approximately $30^{\circ} \mathrm{C}$ and the average minimum was about $20^{\circ} \mathrm{C}$. The rainfall index was high, which is characteristic of the region driving the period when the test was being carried out (Figure 1). 
Table 3. Resistance classification by AUDPC (Area Under Disease Progress Curve).

\begin{tabular}{cc}
\hline AUDPC & Resistance Classification* \\
\hline 1 a 20 & $\mathrm{HS}$ \\
21 a 200 & $\mathrm{R}$ \\
201 a 500 & $\mathrm{MR}$ \\
501 a 1000 & $\mathrm{MS}$ \\
1001 a 2000 & $\mathrm{~S}$ \\
$>2000$ & $\mathrm{HS}$ \\
\hline
\end{tabular}

HS: highly susceptible, S: susceptible, MS: moderately susceptible, MR: moderately resistant, R: resistant and HR: highly resistant.

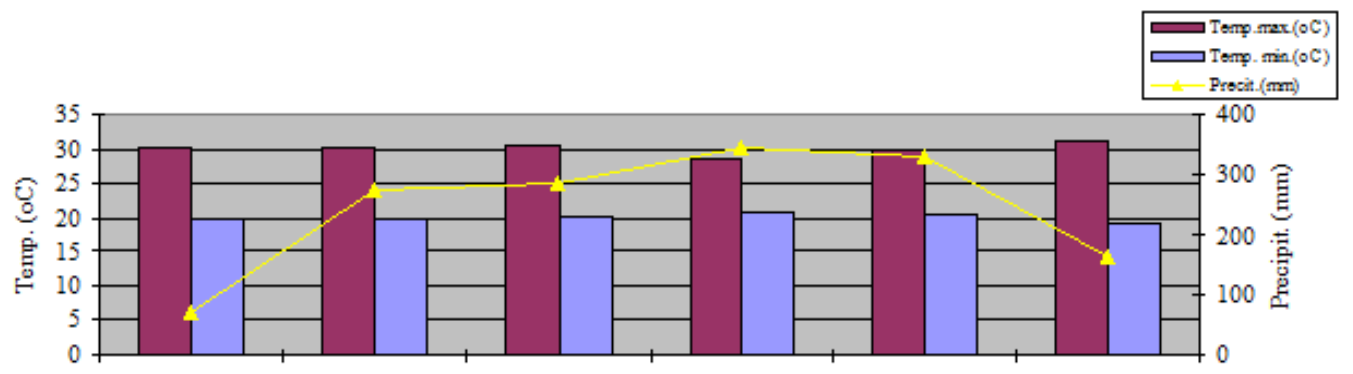

Figure 1. Climatological data from the Research Center of Pioneer Seeds Ltd, from October 2003 to March 2004.

\section{RESULTS AND DISCUSSION}

At 50 d.a.s. only some/slight symptom of polysora rust was noted in the trial. The hybrids which at this stage showed symptoms were later the most susceptible and were classified as highly susceptible both by the AUDPC calculation as well as by assessing the severity of the disease in experimental plot at 30 d.a.f. (Table 4).

There was a great uniformity in the severity of polysora rust among all plants of the plot, allowing for an optimal evaluation of the disease both by AUDPC as well as by assessing the severity at a single time, at 30 d.a.f.. Studies indicate that both methods were also effective in discriminating the level of resistance to $P$. polysora in corn hybrids, allowing for classification in a similar manner (Von Pinho et al., 2000).

The 22 hybrids used in this trial showed different levels of resistance to the pathogen (Table 1). The genotypes that presented themselves as highly susceptible to disease are not indicated by the companies responsible for planting in the environment where the trials were installed, these genotypes just were part of the experiment for the study.

Both methods used in the evaluation enabled the classification of the materials in a similar manner (Table 4). However, the once only or single evaluation at 30 d.a.f. proved to be efficient and more practical, due to the possibility of evaluating a larger number of genotypes in a shorter time frame.

The highly susceptible hybrids and those susceptible to disease presented the first symptoms at 50 d.a.s. (Figure 2), with some uredia on the lower leaves. For the highly susceptible genotypes, the symptoms showed an upward development after 50 d.a.s., colonizing the whole host by the 90 d.a.s. The susceptible hybrids showed an upward development of symptoms from the 70 d.a.s. colonizing an average of $70 \%$ of the host by the 90 d.a.s. (Figure 2).

The moderately resistant genotypes presented symptoms on lower leaves a little before 60 d.a.s. No upward development of the disease as in highly susceptible genotypes was verified, but the symptoms intensified after 70 d.a.s., as in the susceptible genotypes (Figure 2).

The resistant or highly resistant genotypes to the pathogen presented few leaf symptoms, only after 70 d.a.s. and did not develop these symptoms in the upper leaves. Symptoms were limited to the first three lower leaves, without causing visually observed damage (Figure 2). 


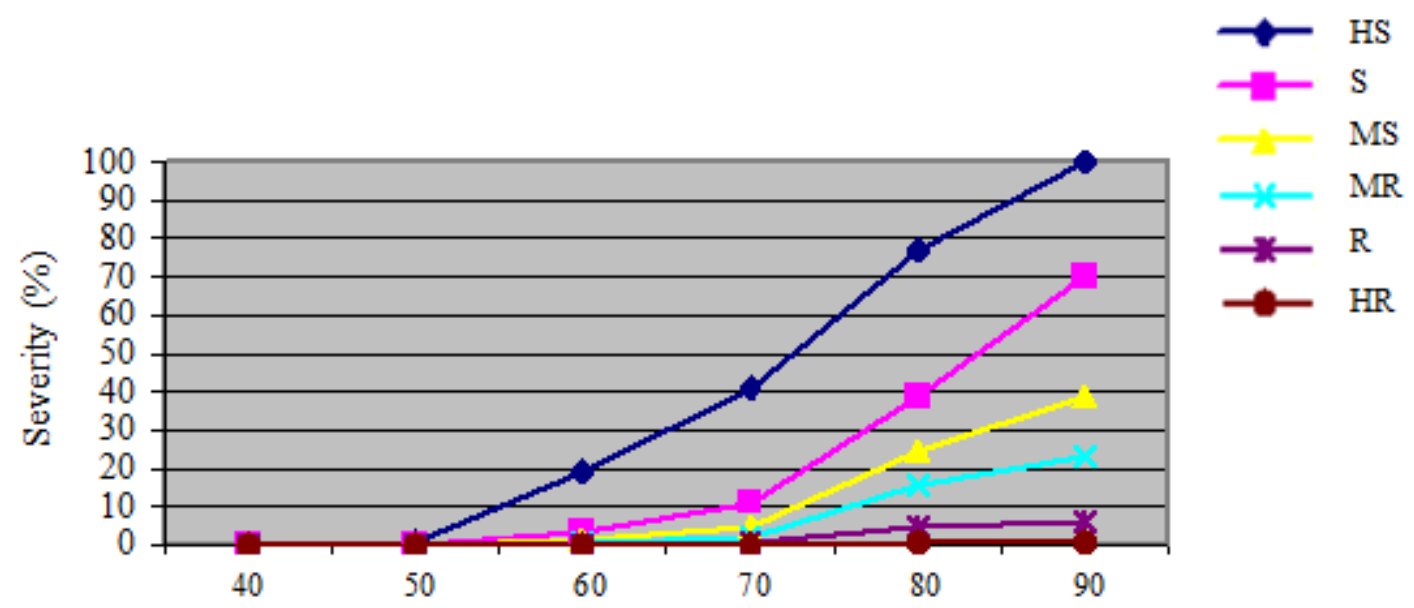

Days after sowing

Figure 2. Temporal evolution of polysora rust in different resistance levels presented by the genetic material HS (highly susceptible), S (susceptible), MS (moderately susceptible), MR (moderately resistant), $\mathrm{R}$ (resistant) and HR (highly resistant) from the calculation of AUDPC. AUDPC evaluated at 40, 50, 60, 70, 80 and 90 days after sowing. Ver cores das linhas em caso de publicação em tons de cinza

Some genotypes showed small differences in classification between the two evaluation methods (Table 4). The AG9010 genotype was classified as resistant by AUDPC and moderately resistant by the evaluation at 30 d.a.f. In this genotype there was an increase in disease severity between 80 and 90 d.a.f. (Figure 3).

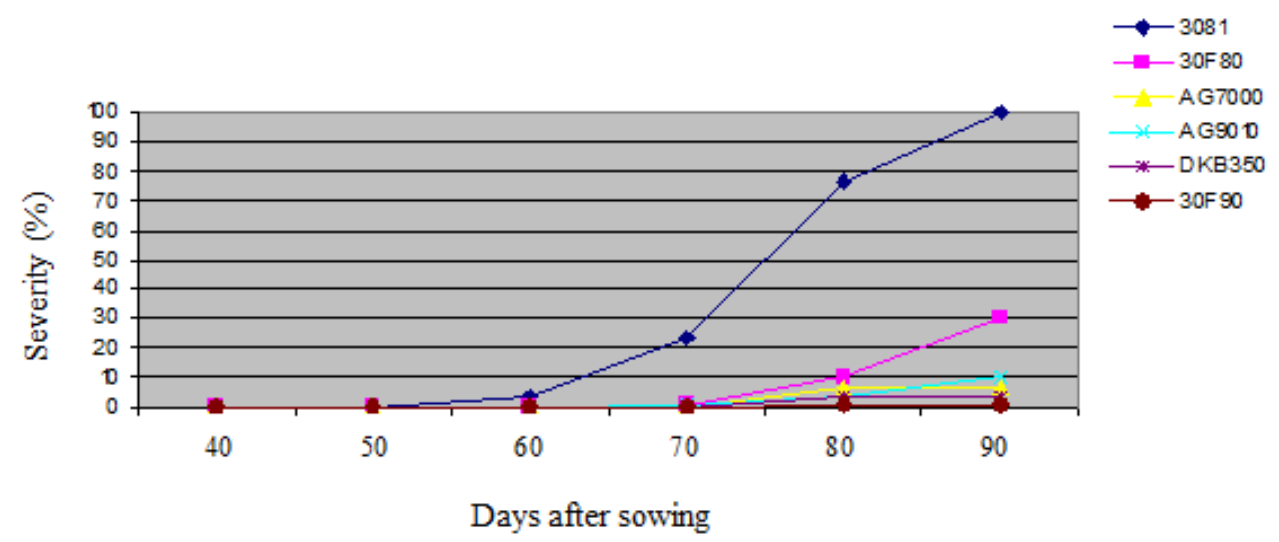

Figure 3. Comparison between AUDPC (Area Under Disease Progress Curve) of AG9010 with other hybrids with different levels of resistance. AUDPC evaluated at 40, 50, 60, 70, 80 and 90 days after sowing. Ver cores das linhas em caso de publicação em tons de cinza

When comparing AG9010 with other genotypes with different resistance levels (3081 AS, 30F80 - MR, AG7000 - R, DKB350, R e $30 \mathrm{~F} 90$ - AR) it was found that AG9010 had a behavior similar to the highly susceptible genotypes from the 80 d.a.s. (Figure 2 and 3).

The Tractor and 30K75 genotypes obtained different resistance classification by both severity assessment methods (Table 4). The Tractor hybrid was classified as susceptible by AUDPC and as moderately susceptible by severity at 30 d.a.f. The $30 \mathrm{~K} 75$ hybrid was classified as moderately resistant by AUDPC and as moderately susceptible by severity. It can be observed by AUDPC values and severity at 30 d.a.f. that both are located in an area of transition between the resistance groups that were classified, as well as AG9010 (Table 4). AG9010, which was classified as resistant by AUDPC and 
moderately resistant by the evaluation at 30 d.a.f., produced $5.273 \mathrm{~kg} \cdot \mathrm{ha}^{-1}$ (Table 5). This showed that even with a good level of resistance, this genotype showed a limited production capacity.

The 30P70, 30F44 and Tractor genotypes were classified as susceptible to $P$. polysora for symptoms of the disease and produced 6,590, 5,650 and $5.678 \mathrm{~kg} \cdot \mathrm{ha}^{-1}$, respectively (Table 5). Therefore, while even presenting high levels of disease severity, these genotypes were highly productive.

The 30F90 genotype was highly resistant to fungus and had high productivity, presenting a high adaptability to the environment in lowland Central Brazil with or without the presence of disease (Tables 4 and 5).

Table 4. Severity of P. polysora on the AUDPC (Area Under Disease Progress Curve), resistance and severity classification in the experimental plot at 30 d.a.f. (days after flowering).

\begin{tabular}{|c|c|c|c|c|}
\hline Genotypes & AUDPC $^{1}$ & $\begin{array}{l}\text { Resistance } \\
\text { AUDCP }^{2}\end{array}$ & $\begin{array}{l}\text { Sev.30 } \\
\text { d.a.f. }{ }^{3}\end{array}$ & $\begin{array}{c}\text { Resistance } \\
\text { Sev.30 d.a.f. }{ }^{4}\end{array}$ \\
\hline $30 \mathrm{~F} 53$ & $2807.0 \mathrm{a}^{*}$ & $\mathrm{HS}$ & $100.0 a^{*}$ & $\mathrm{HS}$ \\
\hline 30R50 & $2807.0 \mathrm{a}$ & HS & $100.0 \mathrm{a}$ & HS \\
\hline 3081 & $2054.7 \mathrm{~b}$ & HS & $100.0 \mathrm{a}$ & HS \\
\hline $30 \mathrm{~F} 44$ & $1238.0 \mathrm{c}$ & $\mathrm{S}$ & $76.7 \mathrm{ab}$ & $\mathrm{S}$ \\
\hline $30 \mathrm{P} 70$ & $1188.0 \mathrm{c}$ & $\mathrm{S}$ & $76.7 \mathrm{ab}$ & $\mathrm{S}$ \\
\hline Tractor & $1043.0 \mathrm{~cd}$ & $\mathrm{~S}$ & $56.7 \mathrm{bcd}$ & MS \\
\hline DKB390 & 707.3 cde & MS & 30.0 def & MS \\
\hline Speed & 679.0 cde & MS & $63.3 \mathrm{bc}$ & MS \\
\hline $30 \mathrm{~F} 33$ & 578.7 cde & MS & $23.3 \mathrm{efg}$ & MR \\
\hline Valent & $429.0 \mathrm{de}$ & MR & $23.3 \mathrm{efg}$ & MR \\
\hline $30 \mathrm{~K} 75$ & $415.0 \mathrm{de}$ & MR & 36.7 cde & MS \\
\hline Fort & $393.0 \mathrm{de}$ & MR & 16.7 efg & MR \\
\hline $2 \mathrm{C} 577$ & $348.3 \mathrm{de}$ & MR & 16.7 efg & MR \\
\hline $30 \mathrm{~F} 80$ & $312.3 \mathrm{de}$ & MR & $23.3 \mathrm{efg}$ & MR \\
\hline $30 \mathrm{~F} 88$ & $149.0 \mathrm{e}$ & $\mathrm{R}$ & $6.7 \mathrm{fg}$ & $\mathrm{R}$ \\
\hline AG7000 & $144.0 \mathrm{e}$ & $\mathrm{R}$ & $6.7 \mathrm{fg}$ & $\mathrm{R}$ \\
\hline AG9010 & $112.3 \mathrm{e}$ & $\mathrm{R}$ & 10.7 efg & MR \\
\hline DKB350 & 80.7 e & $\mathrm{R}$ & $3.3 \mathrm{fg}$ & $\mathrm{R}$ \\
\hline AG7575 & $73.3 \mathrm{e}$ & $\mathrm{R}$ & $3.3 \mathrm{fg}$ & $\mathrm{R}$ \\
\hline $30 \mathrm{~F} 90$ & $17.3 \mathrm{e}$ & HR & $0.0 \mathrm{~g}$ & HR \\
\hline $2 \mathrm{C} 599$ & $14.7 \mathrm{e}$ & HR & $0.0 \mathrm{~g}$ & HR \\
\hline Strike & $12.3 \mathrm{e}$ & HR & $0.0 \mathrm{~g}$ & HR \\
\hline
\end{tabular}

*Averages followed by different letters differ from one another at the level of significance of $1 \%$ of probability by the Tukey test; AUDPC: d.m.s. $5 \%=637.70835$, d.m.s. $1 \%=735.99692$; Severity: d.m.s. $5 \%=23.85753$, d.m.s. $1 \%=27.53464 ;{ }^{1}$ Averages of AUDPC (Area Under the Disease Progress Curve); ${ }^{2}$ Resistance classification according to AUDPC data, with: HS: highly susceptible, S: susceptible, MS: moderately susceptible, MR: moderately resistant, R: resistant and HR: highly resistant; ${ }^{3}$ Averages of disease severity assessed at 30 daf. ${ }^{4}$ Resistance classification according to the severity of disease data assessed at 30 d.a.f. (days after flowering).

Table 5. Resistance classification (AUDPC and evaluation at 30 d.a.f.) and productivity (kg.ha ${ }^{-1}$ ) of corn genotypes.

\begin{tabular}{lcrrl}
\hline Genotypes & $\begin{array}{c}\text { Resistance } \\
\text { 30 d.a.f. }\end{array}$ & $\begin{array}{r}\text { Resistance } \\
\text { AUDPC }\end{array}$ & $\begin{array}{c}\text { Produtctivity } \\
\left(\mathrm{kg}^{2} \mathrm{ha}^{-1}\right)^{3}\end{array}$ \\
\hline 30F53 & HS & HS & $4301.6 \mathrm{~cd}^{* *}$ & B* \\
30R50 & HS & HS & $4481.3 \mathrm{bcd}$ & B \\
3081 & HS & HS & $4020.6 \mathrm{~d}$ & B \\
30F44 & S & S & .5652 .6 abcd & AB \\
30P70 & S & S & 6592.3 abcd & AB \\
TRACTOR & MS & S & 5678.0 abcd & AB \\
DKB390 & MS & MS & 6398.0 abcd & AB \\
SPEED & MS & MS & 6153.6 abcd & AB
\end{tabular}




\begin{tabular}{|c|c|c|c|c|}
\hline $30 \mathrm{~F} 33$ & MR & MS & $6345.6 \mathrm{abcd}$ & $\mathrm{AB}$ \\
\hline VALENT & MR & MR & $5700.0 \mathrm{abcd}$ & $\mathrm{AB}$ \\
\hline $30 \mathrm{~K} 75$ & MS & MR & $6493.0 \mathrm{abcd}$ & $\mathrm{AB}$ \\
\hline FORT & MR & MR & $6348.3 \mathrm{abcd}$ &. $\mathrm{AB}$ \\
\hline $2 \mathrm{C} 577$ & MR & MR & $6371.3 \mathrm{abcd}$ &. $\mathrm{AB}$ \\
\hline $30 F 80$ & MR & MR & $5749.3 \mathrm{abcd}$ & $\mathrm{AB}$ \\
\hline $30 \mathrm{~F} 88$ & $\mathrm{R}$ & $\mathrm{R}$ & $6018.6 \mathrm{abcd}$ & $\mathrm{AB}$ \\
\hline AG7000 & $\mathrm{R}$ & $\mathrm{R}$ & $6310.0 \mathrm{abcd}$ & $\mathrm{AB}$ \\
\hline AG9010 & MR & $\mathrm{R}$ & $5273.3 \mathrm{abcd}$ & $\mathrm{AB}$ \\
\hline DKB350 & $\mathrm{R}$ & $\mathrm{R}$ & $6398.3 \mathrm{abcd}$ & $\mathrm{AB}$ \\
\hline AG7575 & $\mathrm{R}$ & $\mathrm{R}$ & $6097.3 \mathrm{abcd}$ & $\mathrm{AB}$ \\
\hline 30F90 & HR & HR & $7805.3 \mathrm{a}$ & A \\
\hline $2 C 599$ & HR & HR & $6860.3 \mathrm{abc}$ & $\mathrm{AB}$ \\
\hline STRIKE & HR & HR & $7003.0 \mathrm{ab}$ & $\mathrm{AB}$ \\
\hline
\end{tabular}

Averages followed by different letters differ from one another at the significance level of $1 \% *$ or $5 \%$ ** of probability by the Tukey test; AUDPC: d.m.s. 5\% = 637.70835, d.m.s. $1 \%=735.99692$; Productivity: d.m.s. $5 \%=2651.33333$, d.m.s., 1\% = 3059.9774; Variation Coefficient of Productivity: $14 \%$; ${ }^{2}$ Resistance classification according to AUDPC data (HS: highly susceptible, S: susceptible, MS: moderately susceptible, MR: moderately resistant, R: resistant and HR: highly resistant); ${ }^{3}$ Produtctivity $\left(\mathrm{kg}^{\circ} \mathrm{ha}^{-1}\right)$.

Using the correlation of productivity with the severity of the disease evaluated by AUDPC it was possible to observe that there was a negative relationship between productivity and AUDPC of $60 \%(\mathrm{r}=-0,60)$ (data not shown).

The AUDPC correlation with the assessment of severity in a single assessment at 30 d.a.f., was $87 \%$ (data not shown). It is considered, therefore, that as much by means of the AUDPC as by means of the single evaluation after 30 d.a.f., the selection of genotype for resistance to $P$. polysora is possible. Therefore, the evaluation of severity at 30 d.a.f. enables the discrimination of genotypes, reducing labor and time available for this operation, as regards the evaluation by AUDPC. These results corroborate the data found by Von Pinho et al. (2000).

Foss (1999), working with the assessment of damage caused by $P$. polysora in corn, found that the experimental plot method with stand correction was satisfactory for the evaluation of the damage caused by polysora rust in corn production. There is a good correlation between the severity of the disease and AUDPC with production. In relation the popcorn diseases significant differences $(\mathrm{P}$ $\leq 0.01$ ) of resistance to southern rust (Puccinia polysora) northern leaf blight (Exserohilum turcicum) and Phaeosphaeria leaf spot (complex Phaeosphaeria maydis/ Pantoea ananatis) were observed. The cluster analysis detected different resistance levels to the series of leaf diseases. In 12 of the new hybrids the resistance level to the set of disease s was similar as in the commercial hybrid IAC 112, considered the best reference for leaf disease resistance among commercial popcorn genotypes (VIEIRA et al. 2009).

\section{CONCLUSIONS}

The assessment of severity by way of AUDPC and by evaluation at 30 d.a.f. allows one to characterize and classify corn genotypes for resistance to $P$. polysora.

The assessment by AUDPC enables the visualization of the progression of the disease in time for the different levels of resistance of the genotypes. However, the single assessment at 30 d.a.f. was more practical and feasible when one has a large number of genotypes to analyze.

RESUMO: Dentre os organismos biotróficos que atacam a cultura do milho o mais importante para o Brasil Central é a Puccinia polysora Underw, agente causal da ferrugem polysora do milho. Devido à necessidade de se estudar melhor os métodos utilizados nas avaliações, realizou-se este trabalho. Um experimento para identificar a melhor metodologia para avaliação da ferrugem polysora foi montado em Itumbiara - Goiás, com 22 híbridos e o delineamento experimental de blocos casualizados com três repetições. Utilizou-se para as avaliações da severidade da doença em relação à área foliar afetada, a Área Abaixo da Curva de Progresso da Doença (AACPD) e a avaliação única, considerando também a severidade da doença em relação à área foliar afetada, aos 30 dias após florescimento (30 d.a.f.). Ambas 
baseadas na escala diagramática da Agroceres, com notas variando de um (altamente resistente) a nove (altamente suscetível), que foi empregada considerando a parcela com um todo. Para o cálculo da AACPD foram realizadas cinco avaliações da severidade da doença a intervalos de 10 dias e iniciadas aos 50 dias após semeadura. Verificou-se que tanto pela AACPD ou pela avaliação única aos 30 d.a.f. foi possível a determinação do nível de resistência dos genótipos, sendo que a avaliação da severidade da doença através do cálculo da AACPD permite entender melhor a evolução da doença no tempo e a avaliação única aos 30 d.a.f. nos permite trabalhar com um maior número de genótipos, devido à praticidade da metodologia.

PALAVRAS-CHAVE: Puccinia polysora. Avaliação. Doença. Ferrugem.

\section{REFERENCES}

AGRIOS, G. N. Plant pathology. 4. ed. New York: Academic. New York, 1998. 635p.

AGROCERES. Guia Agroceres de sanidade. São Paulo: 1996. 72p.

BOLOW, J. F. W. As ferrugens (P. sorghi, P. polysora, Physopella zeae do milho (Zea mays). I.Revisão bibliográfica. Pesquisa Agropecuária Brasileira, Brasília, DF, v. 1, p.249-262, 1966.

BONDE, M. R.; BROMFIELD, K. R.; MELCHING, J. S. Morfological development of Physopella zeae on corn. Phytopathology, Saint Paul, v. 72, n. 11, p.1489-1491, 1982. http://dx.doi.org/10.1094/Phyto-72-1489

CAB INTERNATIONAL. Crop Protection Compendium. Global Module. 2003.ed. Wallingford, 2003.

FANCELLI, A.L. Ecofisiologia e Fenologia. CAD - Tecnologia da Produção de Milho. Piracicaba: Aldeia Norte, São Paulo. 2002. 52p.

FANTIN, G. M. Avaliação de resistência do milho à ferrugem causada por Puccinia polysora Underw. Piracicaba. 1997. 136p.

FERNANDES, F.T.; OLIVEIRA, E.. Principais doenças na cultura do milho. Sete Lagoas: EMBRAPACNPMS, 2000. 80p.

FOSS, M.R.D. Avaliação de danos causados por Puccinia polysora em milho (Zea mays). 2000. 67f. Dissertação (Mestrado em Genética e Melhoramento de Plantas) - Faculdade de Ciências Agrárias e Veterinárias, Universidade Estadual Paulista “Júlio de Mesquita Filho", Jaboticabal.

GODOY, C. V. et al. Influência da temperatura e do período de molhamento nos parâmetros monocíclicos de Puccnia polysora. Fitopatologia Brasileira, Brasília, DF, v. 20, n. 2, p.184-189, mar. 1995.

GODOY, C.V. Influência de variáveis climáticas no desenvolvimento da ferrugem polysora na cultura do milho. 2000. 79f. Dissertação (Doutorado em Fitopatologia) - Escola Superior de Agricultura "Luiz de Queiroz". Piracicaba.

GODOY, C.V. et al. Temporal progress of southern rust in maize under different enviromental conditions. Fitopatologia Brasileira, Brasilia, DF, v. 28, n.3, p.273-278, May/June 2003. http://dx.doi.org/10.1590/S010041582003000300008

JULIATTI, F.C.; SANTOS, M.A. Métodos de avaliação de doenças de plantas. In: LUZ et al. Revisão anual de patologia de plantas. Passo Fundo, 1999. v. 7, p.407-454.

McGEE, D.C. Maize disease: a reference source for seed technologists. Saint Paul: Ames: American Phytopatological Society, 1988. 150p. http://dx.doi.org/10.1016/S0012-3692(16)30548-7 http://dx.doi.org/10.1016/S0012-3692(16)33573-5 http://dx.doi.org/10.1016/S0012-3692(16)30546-3 
MELCHING, J.S. Corn Rusts: types, races, and destructive potencial. In: ANNUAL CORN AND SORGHUM RESERCH CONFERENCE, 30., 1975. Proceedings...Washington: American Seed Trade Association, 1975. p. 90-115.

OLIVEIRA, E.B.M. Seleção de genitores resistentes a Puccinia polysora, Physopella zeae e Phaeosphaeria maydis em milho. 2001. 79f. Dissertação (Mestrado em Genética e Melhoramento de Plantas) - Universidade Federal de Goiás, Goiânia.

PEREIRA, O. A. P. Doenças do milho (Zea mays L.). In: KIMATHI, H. et al. Manual de fitopatologia. 3. ed. São Paulo: Ceres, 1997. v. 2, p.539-555.

SCHIEBER, E. Distribución de Puccinia polysora y Puccnia sorghi en Africa y su patogenicidad sobre plasma de germen de maiz latinoamericano. Boletín Fitossaniatario de La Fao, St. Paul. v. 19, p.25-31, feb. 1971.

SHERFF, A.F.; MACNAB, A.A. Vegetables diseases and their control: corn. 2.ed. New York: John Wiley \& Sons, 1986. p.232-34.

SHURTLEFF, M. C. Compendium of corn diseases. 2.ed. Saint Paul: American Phytopathological Press, 1992. 105p.

VIEIRA, R. A. et al. Genetic resistance of new popcorn hybrids to foliar diseases. Crop Breeding and Applied Biotechnology, Viçosa, v.9, n.,140146,2009.

VON PINHO R. G. et al. Reação de híbridos comerciais de milho às ferrugens polissora e tropical. Pesquisa Agropecuária Brasileira Brasília, v. 36, n. 3 p. 439-445, mar. 2001. http://dx.doi.org/10.1590/S0100204X2001000300007

VON PINHO, R.G. et al. Comparação de métodos para quantificação da severidade das ferrugens polissora e tropical do milho. Ciências Agrotécnicas, Lavras, v.24, n.1, p.22-36, jan./mar., 2000.

WHITE, D. G. Compendium of corn diseases. 3. ed. St. Paul: American Phytopathological Society. 1999. $78 \mathrm{p}$. 